\title{
Hormonal Regulation of Hepatitis B Virus Gene Expression: Influence of Androgen Receptor
}

\author{
SCOTT BREIDBART, ROBERT D. BURK, AND PAUL SAENGER \\ Departments of Pediatrics /S.B., R.D.B., P.S.J, Microbiology and Immunology'/R.D.B.J, and Obstetrics and \\ Gynecology' [R.D.B.J, Albert Einstein College of Medicine. The Marion Bessin Liver Research Center, and \\ Montefiore Medical Center [R.D.B.J, Bronx, New York 10467
}

\begin{abstract}
Adult HBV-transgenic males produce more hepatitis B surface antigen (HBsAg) in serum than females. The difference decreases with castration and is restored with testosterone replacement. To investigate the contribution of the androgen receptor in this process, $\mathrm{HBV}$ transgenic males were mated with females heterozygous for the testicular feminization mutation (Tfm), an X-linked gene with $90 \%$ reduced androgen receptor. A total of 19 phenotypic HBV-transgenic females were studied, of which eight $X Y^{\mathrm{T} f m}$ females were identified by the presence of $\mathrm{Y}$ chromosome DNA using molecular hybridization. The 11 normal $(X X)$ females had $11.7 \pm 3.5 \mu \mathrm{g} / \mathrm{mL}$ (mean \pm SD) of HBsAg in their serum, whereas the Tfm (XY) females had $17.1 \pm 5.9 \mu \mathrm{g} / \mathrm{mL}(p<0.05)$. However, the Tfm $(X Y)$ females produced less HBsAg than 33 normal (XY) males $(41 \pm 12 \mu \mathrm{g} / \mathrm{mL})$, and the overall ratio of male/female HBsAg levels was reduced: $\mathrm{XY} / \mathrm{XX}=3$ versus $X \mathrm{Y}^{\mathrm{1fm}} / \mathrm{XX}$ $=1.5$. Although dexamethasone caused an increase in $\mathrm{XY}^{\mathrm{T} / \mathrm{m}}$ and $\mathrm{XX}$ mice, testosterone did not increase $\mathrm{HBs} \mathrm{Ag}$ in $X Y^{\text {Tfm }}$. These data indicate that hepatitis $B$ expression as measured by HBsAg levels in this animal model is mediated through an androgen receptor. (Pediatr Res 34: 300-302, 1993)
\end{abstract}

Abbreviations
HBV, hepatitis B virus
HBsAg, hepatitis B surface antigen
Tfm, testicular feminization

$\mathrm{HBV}$ is a partially double-stranded DNA virus approximately $42 \mathrm{~nm}$ in diameter (1). The clinical manifestations of infection with $\mathrm{HBV}$ are heterogeneous and vary from asymptomatic, particularly in children, to fulminant hepatitis (1). Most children who are infected perinatally become chronic carriers of $\mathrm{HBV}(2)$. Chronic carriers are at an increased risk for cirrhosis and hepatocellular carcinoma (2). In particular, male chronic carriers of HBV have a 3- to ten-fold increased incidence of hepatocellular carcinoma compared with female chronic carriers (3).

The transgenic mouse model of chronic HBsAg has been developed independently by several groups (for review see Reference 4). The HBV transgene sequences are expressed preferentially in the liver and proximal tubule of the kidney, and the serum concentration of HBsAg can be used as a marker for viral gene expression. Male transgenic mice have higher $\mathrm{HBsAg}$ levels

Received September 29, 1992; accepted March 30, 1993.

Correspondence: Paul Saenger, M.D., Department of Pediatrics, Montefiore Medical Center, 111 East 210th St., Bronx, New York, 10467.

Supported in part by a training grant in investigative endocrinology (2-T32-DK07004-16) (S.B.), National Institutes of Health Grant CA-45476 from the National Cancer Institute, and by a grant from the Sinsheimer Foundation. than female transgenic mice (5-7). The castration of male transgenics resulted in the lowering of the $\mathrm{HBsAg}$ concentration (5. 8 ). Thus, it appears that testosterone is responsible at least partially for the increased HBV levels seen in males.

Testosterone may increase the HBsAg concentration through its action on the androgen receptor. To test this hypothesis, we have used the following rationale. We compared the surface antigen levels of transgenic XY mice without functioning androgen receptors to the levels in female mice. If the androgen receptor-androgen complex is responsible for the increased levels in males, male transgenic mice lacking androgen receptors should have a similar surface antigen concentration as do females.

There is a well-known strain of mice that contains an X-linked mutation causing the absence of the androgen receptor in affected mice $(9,10)$. This defect is analogous to the testicular feminization syndrome in humans. All known androgen target cells, embryonic Wolffian ducts and urogenital sinus, hypothalamicpituitary axis, proximal kidney tubules, and submaxillary glands in this Tfm mouse are insensitive to testosterone (10-12). Glucocorticoids also have been described to stimulate the expression of $\operatorname{HBsAg}(5,8)$.

\section{MATERIALS AND METHODS}

Animals. The G26 HBV transgenic mouse line used in this study has been described previously (6). Female mice heterozygous for the testicular feminization gene were obtained from Jackson Laboratories (Bar Harbor, ME).

For the glucocorticoid experiments, all animals were bled before injection, injected with dexamethasone $(0.1 \mathrm{~mL}$ Hexadrol phosphate $[20 \mathrm{mg} / \mathrm{mL}]$, Organon, Inc., West Orange, $\mathrm{NJ}$ ) and bled at $\mathrm{d} 0,3,6$, and 10 . In an equal number of mice who were untreated, HBsAg level variability was measured on d $0,3,6$, and 10.

For the testosterone experiments, animals received testosterone enanthate $20 \mathrm{mg}$ intraperitoneally (Gynex, Vernon Hills, IL), and they were bled on $\mathrm{d} 0$ and 3.

Clinical chemistry. Serum HBsAg levels were determined using the AUSRIA II solid phase RIA kit (Abbott Laboratories, North Chicago, IL). The levels were quantified by comparison to a standard curve generated from a purified sample of HBsAg 40 $\mu \mathrm{g} / \mathrm{mL}$ (provided by Merck Sharp \& Dohme Research Laboratory, West Point, PA) serially diluted in human serum that was negative for $\mathrm{HBsAg}$ and anti-HBsAg. Transgenic mouse sera to be quantified were diluted 500 -fold to be in the linear portion of the curve. Curve fitting and interpolation were done using the four-parameter logistic function as described (13).

The interassay coefficient of variation and the intraassay coefficient of variation were $<10 \%$.

DNA analysis. To determine the presence of a $\mathrm{Y}$ chromosome. DNA was extracted from tail segments and assayed by Southern analysis for the presence of $\mathrm{Y}$ chromosomal DNA. Five $\mu \mathrm{g}$ of DNA were digested with EcoRI, electrophoresed through a $0.8 \%$ 
agarose gel, blotted, and hybridized with a Y-chromosome DNA probe. The Y-chromosome probe was kindly provided by Dr. E. Palmer (14). The cloned inset Y-chromosome DNA fragment was gel purified from the $\mathrm{pY} 1$ plasmid and labeled to high specific activity $(>1 \times 108 \mathrm{cpm} / \mu \mathrm{g})$ random primer extension (15). The blots were hybridized under stringent conditions $[$ i.e. $5 \times \mathrm{SSC}$ $(0.75 \mathrm{M} \mathrm{NaCl}+0.075 \mathrm{M}$ sodium citrate), $50 \%$ formamide at $42^{\circ} \mathrm{C}$ ] for $48 \mathrm{~h}$, washed extensively in $0.1 \mathrm{SSC}, 0.5 \% \mathrm{SDS}$ at $60^{\circ} \mathrm{C}$, and exposed to x-ray film (Kodak X-Omat) for $48 \mathrm{~h}$.

\section{RESULTS}

To generate HBV transgenic mice that lack the androgen receptor, we crossed G26 males homozygous for the HBV transgene with female mice carrying the Tfm mutation. Twenty progeny were produced. Nineteen were phenotypic females, one was a phenotypic male. All progeny were heterozygous for the hepatitis B transgene. In addition, the resultant progeny were $\mathrm{XY}$ males, males that contained the Tfm mutation and appear phenotypically female, or XX females, some of which carry the Tfm mutation. Thus, of the phenotypic females, mice with a $Y$ chromosome lack the androgen receptor. To distinguish genotypic male mice containing the $\mathrm{Tfm}$ mutation from $\mathrm{XX}$ female mice, we probed all the phenotypic females for Y-chromosome DNA by Southern blot hybridization using a mouse $\mathrm{Y}$-chromosome DNA probe specific for the mouse $\mathrm{Y}$ chromosome (Fig. 1). Lanes 1 through 3 demonstrate the presence of Y-chromosome DNA fragments to be 2.2 and $2.0 \mathrm{~kb}$ in size. Therefore, the phenotypic females containing $\mathrm{Y}$-chromosome DNA are $\mathrm{Tfm}$ mice. Lanes 4 through 6,8 , and 9 were from normal $X X$ female mice and thus do not hybridize with the Y-chromosome probe. In total, the $F_{1} G 26$ homozygous $X^{\mathrm{Tfm}}$ heterozygous cross produced $11 \mathrm{XX}$ females, eight XY females, and one XY male. For unknown reasons, additional crosses with the $X X^{\text {tfm }}$ females failed to yield more $X Y$ transgenic males. We have, therefore, included $\mathrm{HBsAg}$ levels of 32 additional $\mathrm{XY}$ transgenics from previous experiments.

The HBsAg levels in the 52 mice from the transgenic cross were determined on samples obtained at approximately 6 mo of

Phenotypic Females

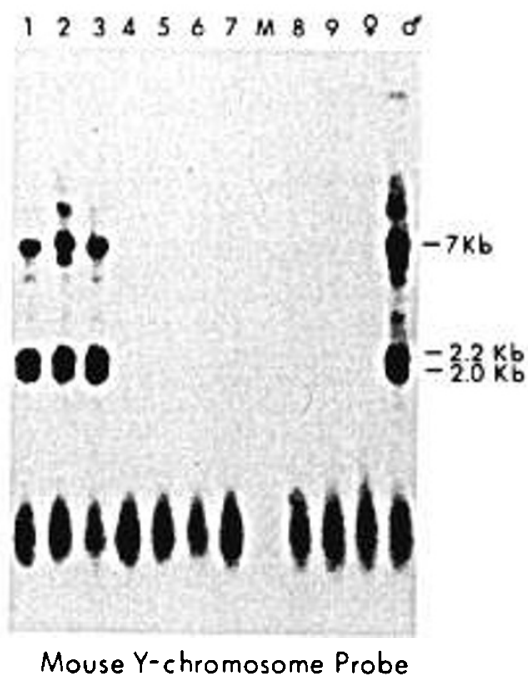

Fig. 1. Southern blot detection of mouse Y-chromosome DNA. Genomic DNA was isolated from a distal segment of the tail obtained from all phenotypic female mice. DNA $(5 \mu \mathrm{g})$ was digested with EcoRI, electrophoresed through $0.8 \%$ agarose gel, and a Southern blot was performed with a mouse Y-chromosome DNA probe as described in Materials and Methods. Lanes $1-9$ contain sample DNA; $M$, marker DNA; wild type male and female DNA are indicated by symbols. The EcoRII Y-chromosome DNA fragments hybridizing with the probe were $7.0 \mathrm{~kb}, 2.2 \mathrm{~kb}$, and $2.0 \mathrm{~kb}$ as indicated.

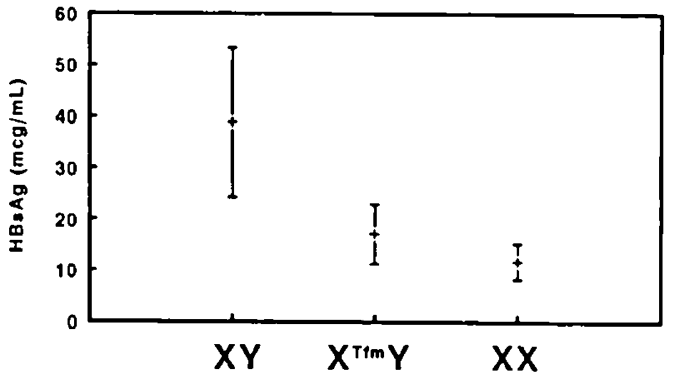

Fig. 2. Levels of $\mathrm{HBsAg}(\mu \mathrm{g} / \mathrm{mL})$ in the 52 mice produced by a cross of a G26 male mouse homozygous for the hepatitis B transgene and a female mouse carrier of the Tfm mutation. Mean \pm SD is shown for $\mathrm{X}^{\mathrm{Tfm}} \mathrm{Y}$ mice $(n=8), \mathrm{XX}$ mice $(n=11)$, and $\mathrm{XY}$ mice $(n=33)$.

\section{HBsAg Level Variability}



Dexamethasone Effect On HBsAg Levels

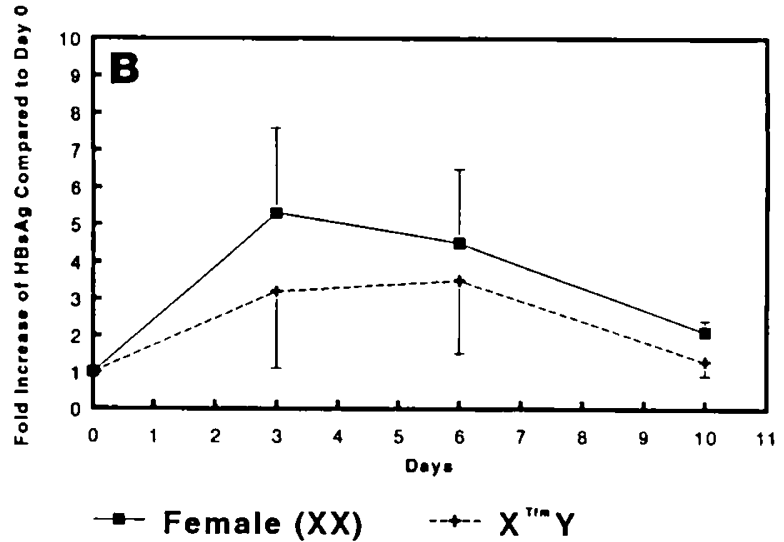

Fig. 3. A, Ratio to $\mathrm{d} 0$ of HBsAg in $\mathrm{XX}$ mice $(n=4)$ and $\mathrm{X}^{\mathrm{Tfm}} \mathrm{Y}$ mice $(n=4)$ heterozygous for the hepatitis $\mathrm{B}$ transgene. Dexamethasone $2 \mathrm{mg}$ intraperitoneally was given on $\mathrm{d} 0$, and blood was sampled on $\mathrm{d} 0$, 3,6 , and $10 . B$, Variability of $\mathrm{HBsAg}$ levels. Ratio to $\mathrm{d} 0$ of $\mathrm{HBsAg}$ in $\mathrm{XX}$ mice $(n=4)$ heterozygous for the hepatitis $\mathrm{B}$ transgene. The study also was done for comparison with the experiment pictured in $A$.

age (Fig. 2). The male mice produced substantially more serum HBsAg $(41 \pm 12 \mu \mathrm{g} / \mathrm{mL}$; range, 25-55) than did the female mice $(p<0.001)$. The $\mathrm{X}^{\mathrm{Tfm}} \mathrm{Y}(n=8)$ mice produced significantly more HBsAg $17.1 \pm 5.9 \mu \mathrm{g} / \mathrm{mL}$; (range, 11.2-23.0) than did the $\mathrm{XX} / \mathrm{X}^{\mathrm{Tfm}} \mathrm{X}(n=11)$ mice $(11.7 \pm 3.5$; range, $8.2-15.2)(p<$ $0.05, t$ test $)$

To determine whether the androgen receptor might influence the glucocorticoid mediated stimulation of $\mathrm{HBsAg}$ production, $X^{\mathrm{Tfm}} Y$ and $\mathrm{XX}$ mice were injected with $2 \mathrm{mg}$ dexamethasone 




Fig. 4. Effect of testosterone enanthate $20 \mathrm{mg}$ intraperitoneally on HBsAg levels in $\mathrm{X}^{\mathrm{Tfm}} \mathrm{Y}(n=4)$ and normal female $\mathrm{XX}(n=4)$ mice $(p$ $<0.05$ ). Ratio to $\mathrm{d} 0$ is shown.

intramuscularly and monitored for $10 \mathrm{~d}$ for serum HBsAg expression (Fig. 3A). In a control experiment, female (XX) G26 mice were injected with saline and were sampled for HBsAg on d 0 , 3,6 , and 10 . Results of variability of $\mathrm{HBsAg}$ levels are shown in Figure $3 B$. Dexamethasone caused a rise in HBsAg levels in $\mathrm{Tfm}$ animals when compared with baseline that is not statistically significantly different from the rise seen in normal females $(p>$ $0.1)$.

Because Tfm mice also are androgen deficient (serum testosterone levels approximately one third of those of normal males), $20 \mathrm{mg}$ of testosterone enanthate was injected on $\mathrm{d} 0$, and the increase in HBsAg levels on d 3 compared with d 0 is shown in Figure 4.

\section{DISCUSSION}

Male transgenic mice produce higher serum HBsAg levels than female transgenic mice (5-7). Female transgenic mice given testosterone increase their levels of $\mathrm{HBsAg}$, but not to male levels $(5,8)$. The male-female difference has been attributed to the greater amount of testosterone in males, and the male-testosterone supplement and female difference have been attributed to the different amount of liver androgen receptors in male and female mice (8).

We found that the male-female serum HBsAg level difference is due, at least in part, to the presence of androgen receptors. The male mouse had more serum HBsAg than did the female mice, and the male to female $\mathrm{HBsAg}$ ratio was substantially greater than the $\mathrm{X}^{\mathrm{Tfm}} \mathrm{Y}$ to $\mathrm{XX}$ HBsAg ratio. It is surprising there is a difference between the serum HBsAg levels in XX female and $X^{\text {Tfm }} Y$ female mice. This difference is probably not due to an inhibitory modulation by estrogen in XX female mice because estrogen also has been shown to stimulate HBsAg production in transgenic mice (5). The difference is probably not due to aromatization of androgens causing increased estrogen levels be- cause testicular feminized mice produce only one third of the normal amount of testosterone after puberty (16).

Conversely, glucocorticoids stimulated the expression of $\mathrm{HBsAg}$ gene markedly in a time-dependent fashion. Because the stimulation was nearly identical in $X X$ and $X^{\mathrm{Tfm}} Y$ mice, we conclude that the effect of glucocorticoids on HBsAg levels is not mediated by the androgen receptor. This is in agreement with data published by Farza et al. (5).

To be certain that the androgen effect demonstrated in this study is indeed mediated via the androgen receptor, we treated $\mathrm{XX}$ female mice and $\mathrm{Tfm}$ mice with testosterone enanthate. The rise in $\mathrm{HBsAg}$ after testosterone was significant in female mice and negligible in Tfm mice. The rise in XX female mice was of similar magnitude as reported by Farza et al. (5) in castrated female transgenic mice.

Based on these results, we can speculate that the ditterence in HBsAg protein expression between XY mice lacking the androgen receptor and $\mathrm{XX}$ mice may be due to nonandrogenic causes of sexual dimorphism determining levels of expression of the HBsAg gene.

\section{REFERENCES}

1. Hollinger FB 1990 Hepatitis B virus. In: Fields BN, Knipe DM (eds) Virology, 2nd Ed, Raven Press, New York, pp 2171-2173

2. Hadler SC, Margolis HS 1989 Viral hepatitis. In: Evans AS (ed) Viral Infections of Humans. Plenum Medical Book Co, New York.

3. Kew MC 1986 The development of hepatocellular cancer in humans. Cancer Surveys 5:719-739

4. Chisari FV 1991 Analysis of hepadnavırus gene expression, biology, and pathogenesis in the transgenic mouse. Curr Top Microbiol Immunol 168:85101

5. Farza H, Salmon AM, Hadchouel M, Moreau JL, Babinet C, Tiollais P. Pourcel C 1987 Hepatitis B surface antigen gene expression is regulated by sex steroids and glucocorticoids in transgenic mice. Proc Natl Acad Sci USA 84:1187-1191

6. Burk RD, DeLoia JA, Elawady MK, Gearhart JD 1988 Tissue preferential expression of the hepatitis $B$ virus (HBV) surface antigen gene in two lines of HBV transgenic mice. J Virol 62:649-654

7. Chisari FV, Klopchin K. Moriyama T, Pasquinelli C, Dunsford HA, Sell S, Pinkert CA, Brinster RL, Palmiter RD 1989 Molecular pathogenesis of hepatocellular carcinoma in hepatitis B virus transgenic mice. Cell 59:11451156

8. DeLoia JA, Burk RD, Gearhart JA 1989 Expression of HBsAg varies with the developmental stage and hormonal status of HBV transgenic mice. J Virol 63:4069-4073

9. Lyon MF, Hawkes SG 1970 X-linked gene for testicular feminization in the mouse. Nature 227:1217-1219

10. Attardi B, Ohno S 1974 Cytosol androgen receptor from kidney of normal and testicular feminized (Tfm) mice. Cell 2:205-212

11. Lyon MF, Hendry I, Short RV 1973 The submaxillary salivary glands as test organs for response to androgen in mice with testicular feminization. J Endocrinol 58:357-362

12. Migeon BR, Brown TR, Axelman J, Migeon CJ 1981 Studies of the locus for androgen receptor: localization on the human $X$ chromosome and evidence for the homology with the Tfm locus in the mouse. Proc Natl Acad Sci USA 78:6339-6343

13. Rodbard D, Hutt DM 1974 Statistical analysis of radioimmunoassays and immunoradiometric (labelled antibody) assays. In: Radioimmunoassays and Related Procedures in Medicine. Vol I. International Atomic Energy Agency, Vienna, pp 165-192

14. Lamar EE, Palmer E 1984 Y-coded, species-specific DNA in mice: evidence that the $Y$ chromosome exists in two polymorphic forms in inbred strains. Cell 37:171-177

15. Feinberg AP, Vogelstein B 1983 A technique for radiolabeling DNA restriction endonuclease fragments to high specific activity. Ana! Biochem 132:6-13

16. Ohno S 1974 Testicular feminization. Am J Pathol 76:589-592 